\title{
The Effect of Competence, Work Ethic, Work Discipline, and Work Motivation on Performance of Government Employee in Mentawai Islands District Health Office
}

\author{
Riama Katarina Hutagalung ${ }^{1}$, Elvi Nadear $\mathrm{Purba}^{2}$, Jhonson Tungkir Silalahi ${ }^{3}$, \\ Anne Putri ${ }^{4 *}$ \\ 1, 2, ${ }^{3}$ Magister of Management Sekolah Tinggi Ilmu Ekonomi KBP \\ Padang, Indonesia \\ ${ }^{4}$ Sekolah Tinggi Ilmu Ekonomi Haji Agus Salim, Bukittinggi, Indonesia
}

\begin{abstract}
This study aims to determine the effect of competence, work ethic, work discipline, and work motivation on the performance of the government employee. This research is motivated by the ability or competence of the government employee is still low, not all government employee comply with regulations provided by the agency, agency performance targets have not been achieved, the work ethic is still low, the motivation that supports the performance of the government employee is not optimal, awareness responsibility and work discipline are still low. the performance of the government employee is still unstable at the Mentawai Islands District Health Office.
\end{abstract}

This type of research uses a quantitative approach with multiple linear regression methods. Data collection techniques with questionnaires, observation and interviews. The respondents of this study were 60 government employees in the Mentawai Islands District Health Office. The sampling method uses the total sampling method in which the entire population in this study is the research sample. Hypothesis testing was calculated with the IBM Statistical Package for Social Science (SPSS) program version 24.0.

From the results of this study it was found that competency partially has a significant effect on the performance of the government employee, work ethic partially has a significant effect on the performance of the government employee, work discipline partially has a significant effect on the performance of the government employee, work motivation partially has a significant effect on the performance of the government employee and competence $\left(\mathbf{X}_{1}\right)$, work ethic $\left(\mathbf{X}_{2}\right)$, work discipline $\left(\mathbf{X}_{3}\right)$, and work motivation $\left(\mathbf{X}_{4}\right)$ together have a significant effect on the performance of the government employee in the Mentawai Islands District Health Office.

Keywords:- competence, work ethic, work discipline, work motivation, government employee performance.

\section{INTRODUCTION}

The government employee is located as an element of the state apparatus whose duty is to provide services to the community in a professional, honest, fair and equitable manner in the implementation of state, government and development tasks to the community based on loyalty and adherence to the Pancasila and the 1945 Constitution.

Human Resources has an important role for the organization because human resources as the manager of the system, so that the system continues to run, of course in its management must pay attention to important aspects such as competence, work ethic, discipline, education and training as well as the comfort level of work so that the ASN concerned can be motivated to provide all capabilities in accordance with what is needed by the organization. Human Resources with good performance will ultimately result in a good ASN performance.

Performance is the result of quality and quantity of work achieved by someone in carrying out their duties in accordance with the responsibilities given to him Mangkunegara, (2012: 9). Furthermore, performance is an action or implementation of tasks that can be measured in general performance measures including: quality of work, quantity of work, knowledge of work, and work planning (Sutisna, 2012).

This research was conducted at the Mentawai Islands District Health Office. ASN performance contained in the Mentawai Islands District Health Office is the result of every ASN performance in it that has been given the duties and responsibilities. Therefore, the overall performance of the Mentawai Islands District Health Office will be reflected in the results of the achievement of the Mentawai Islands District Health Office's performance in implementing the defined program activities. However, in reality the performance of ASN in the Mentawai Islands District Health Office is still relatively low as evidenced in the table 1. From the table 1 shows that the indicator of low ASN can be seen from: as many as 25 people (42\%) did not complete the tasks given on time, as many as 30 people 
(51\%) ASN worked not in accordance with the set working hours, as many as 30 people ( $50 \%$ ) ASN whose attendance has never been done by ASN, except under certain conditions, as many as 25 people (42\%) cooperation between ASN is not good and harmonious, and as many as 40 people $(67 \%)$ ASN who do not make use of useful activities hours empty work.

\begin{tabular}{|c|c|c|c|}
\hline No & Indicator & Total & Percentage (\%) \\
\hline 1. & ASN did not complete the assignments in a timely manner. (Inaccurate completion of \\
tasks) & 25 & 42 \\
\hline 2. & ASN works not according to the set working hours. (Working hours mismatch) & 30 & 50 \\
\hline 3. & ASN that is absent has never been done by ASN, except under certain conditions. (Level \\
of attendance) & 30 & 50 \\
\hline 4. & Cooperation between ASN is not good and harmonious. (Lack of cooperation) & 25 & 42 \\
\hline 5. & Many ASN do not make use of activities that benefit empty work hours. (Low work \\
initiative) & 40 & 67 \\
\hline
\end{tabular}

Table 1:- Low Indicator of ASN Performance

Source: Authors' Initial Survey 2019.

The achievement of the performance of the Mentawai Islands District Health Office is inseparable from the performance of ASN, one of the efforts of the agency in maintaining ASN performance is by paying attention to ASN's competence. According to Simanjuntak (2005, p.113) competence can deepen and expand work skills. The more often a person does the same work, the more skilled and the faster he completes the work. As the results of Mokhlas's research (2015), that competence has a positive and significant effect on employee performance. And the same thing was also conveyed by Bakri (2015) that Competence had a positive and significant effect on employee performance at PT. Hadji Kalla in Makassar.
The Mentawai Islands District Health Office has ASN with competencies that do not support each other between their education, work experience, and training. Examples of positions as a competent financial manager required D3 Management / Accounting education, but held by someone from another department. There are also a number of functional positions such as archivists (archival managers) carried out by ASN that are not in accordance with their competencies. Based on the pre-survey conducted by researchers at the Mentawai Islands District Health Office, it was found that ASN competence was still low which is presented in the table below:

\begin{tabular}{|c|c|c|c|}
\hline No. & Indicator & Total & Percentage (\%) \\
\hline 1. & ASN does not have the knowledge and skills to support its work. & 35 & 58 \\
\hline 2. & ASN does not attempt to apply educational background to the work currently being \\
undertaken. & 45 & 75 \\
\hline 3. & ASN rarely raises new ideas for organizational progress (lacks expertise / knowledge). & 45 & 75 \\
\hline 4. & ASN has never attended training organizational skills. & 50 & 83 \\
\hline
\end{tabular}

Table 2:- Low Indicator of ASN Competence

Source: Competency Pre-Survey, Authors 2019.

The pre-survey results showed 35 people $(58 \%)$ said that ASN did not have the knowledge and skills to support their work, as many as 45 people $(75 \%)$ said that ASN did not try to apply their educational background to the current work, as much as 45 people (75\%) said that ASN rarely raises new ideas for organizational progress and in the meantime, as many as 50 people $(83 \%)$ said that the indicator of ASN low competency seen from ASN had never attended a skills training organized by the organization.

In addition to competencies that need to be considered in improving ASN performance, one of them is work ethic. According to Sinamo (2011) work ethic is a set of positive work behavior that is rooted in strong cooperation, fundamental beliefs, accompanied by total commitment to an integral work paradigm. In the research of Wahid I. A. (2016) that the Work Ethic has a positive and significant effect on the performance of civil servants in the Morowali District Forestry and Plantation Service. This result is also supported by Mogot H. Y., et al (2019) that work ethic partially has a significant effect on Employee Performance at PT. PLN Manado Branch.

The work ethic of the ASN Mentawai Islands District Health Office can be seen from their hard work such as working overtime, but some ASN do not take advantage of existing work hours and tend to reduce their work hours. From observations made by many of the ASN who fill their work time by sitting around chatting, or leaving the office for matters not related to their work assignments. ASN also has a low perseverance. Seen from work not completed because it is effectes by low discipline in work, low compliance, low sense of responsibility, and does not show professional skills at work.

Work discipline is also important in improving ASN performance. According to Hasibuan (2013: 23) stressing discipline is the most important function of Human Resource Management and the key to the realization of 
goals because without good discipline it is difficult to realize maximum goals. In the Mentawai Islands District Health Office there are several ASN with a low level of discipline, as evidenced by the low level of employee attendance and inaccuracy when coming to work. The low level of ASN discipline in the Mentawai Islands District Health Office is that ASN is not given much attention to existing regulations, there are no severe sanctions for employees who violate, and less attention from superiors to subordinates.

According to Hartati, et al (2016) that employee work discipline had a positive and significant effect on the performance of the Soppeng District PSDA, Mining and Energy Service employees. And similar research results were also conveyed by Wahid I. A. (2016) that work discipline had a positive and significant effect on the performance of civil servants in the Morowali District Forestry and Plantation Service.

The results of interviews with the Head of the Mentawai Islands District Health Office, it is known that overall ASN work discipline is not optimal. Based on field observations, some ASN conditions do not comply with regulations set by the agency. This can be seen by the fact that there are still ASNs that do not comply with agency regulations such as dressing neatly and not wearing footwear in accordance with agency regulations. If this continues, it can be detrimental to the agency. In the opinion of the Head of the Mentawai Islands District Health Office said that the decline in ASN performance in terms of indicators of mismatched working hours can be seen from ASN which often arrives late. ASN work delays that are still high are evidenced in the following data:

\begin{tabular}{|c|c|c|c|c|c|}
\hline \multirow{2}{*}{ Month } & \multicolumn{3}{|c|}{ Time Delay } & \multirow{2}{*}{$\begin{array}{c}\text { Delay } \\
\text { Amount }\end{array}$} & \multirow{2}{*}{ Persentage $(\%)$} \\
\hline & $<\mathbf{1 0}$ minute & 10-15 minute & $\mathbf{1 5}<$ minute & & \\
\hline January & 20 & 15 & 5 & 40 & 67 \\
\hline February & 15 & 10 & 5 & 30 & 50 \\
\hline March & 17 & 8 & 2 & 27 & 45 \\
\hline April & 15 & 10 & 3 & 28 & 47 \\
\hline May & 18 & 12 & 2 & 32 & 53 \\
\hline June & 16 & 10 & 3 & 29 & 48 \\
\hline Average & 19 & 11 & 3 & 31 & 52 \\
\hline
\end{tabular}

Table 3:- List of ASN Delay Amounts

Source: Secondary Data, Mentawai Islands District Health Office, 2019.

From the above table it can be said that many ASNs who are late coming to work are on average for delays $<10$ minutes, 19 people, for delays of 10-15 minutes, 11 people and for delays $>10$ minutes, 3 people. So the percentage of delay from ASN is $52 \%$, meaning there are around $31 \mathrm{ASN}$ people in the last 6 (six) months who came late. This shows the lack of responsibility and obligation of the ASN for the work given to them.
According to Masyjui (2005) in Sudarmanto (2009) an employee who has a high work discipline can be seen from: timeliness, using office equipment properly, high responsibility, and adherence to office rules. However, according to a statement from the Head of the Mentawai Islands District Health Office it is known that so far the low discipline of ASN is indicated by several things presented in the following table:

\begin{tabular}{|c|c|c|c|}
\hline No. & Indicator & Total & Persentage (\%) \\
\hline 1. & ASN inaccuracy in completing tasks. & 40 & 67 \\
\hline 2. & ASN does not use office equipment properly. & 32 & 53 \\
\hline 3. & ASN responsibility for the tasks performed is still low. & 43 & 72 \\
\hline 4. & ASN does not comply with office regulations. & 45 & 75 \\
\hline
\end{tabular}

Table 4:- Low Work Discipline Pre-Survey

Source: Pre-Survey Work Discipline, Authors 2019.

From the table above shows the results of the survey as many as 40 people $(67 \%)$ indicators of low work discipline seen from the inaccuracy of ASN in completing tasks, as many as 32 people $(53 \%)$ said that the low work discipline seen from ASN did not use office equipment properly. Meanwhile, as many as 43 people (72\%) said that the low work discipline is seen from the responsibility of ASN for the tasks performed is still low, and as many as 45 people $(75 \%)$ the low ASN work discipline seen from ASN does not comply with office regulations.
Based on these problems, it is clear that the human factor is the starting point, the human factor referred to by the researcher is the ASN that carries out its tasks responsibly, efficiently and effectively in accordance with the work plan that has been set, which is why the researcher is interested in further researching about competence, work ethic and work discipline in relation to efforts to improve ASN performance as a thesis preparation material with the title: "Effect of Competence, Work Ethics, Work Discipline, and Work Motivation on Performance of SGovernment Employee in the Mentawai Islands District Health Office". 


\section{ASN Performance}

According to Mangkunegara (2012, p.67) stated that performance is the work of quality and quantity achieved by an employee in carrying out their duties in accordance with the responsibilities given. According to Mangkunegara (2012) performance indicators consist of: (a) tidiness, (b) ability, (c) success, (d) speed, (e) satisfaction, (f) work results, (g) decision making, (h) facilities and infrastructure, (i) compactness, (j) good relations with colleagues and superiors, and $(\mathrm{k})$ independence.

\section{$>$ Competence}

According to Sutrisno (2009, p.202) competence is an ability based on skills and knowledge that is supported by work attitudes that refer to specified work requirements. According to Ruky A., (2006) states that there are several competency indicators which include: (a) consistent, (b) attitude, (c) value system, (d) information, (e) scope of work, (f) ability to complete technical tasks , (g) ability to complete managerial tasks, (h) directing, and (i) guiding.

\section{Work Ethic}

According to Sinamo (2011, p.55) work ethic is the totality of one's personality and ways of expressing, seeing, believing, and giving meaning to something, which encourages oneself to act and achieve optimal charity. And according to Sinamo (2011, p.55) states in that the work ethic indicator consists of: (a) work is art, (b) work is honor, (c) work is actualization, (d) work is mandate, (e) work is a vocation, (f) work is a blessing, (g) work is worship, and (h) work is service.

\section{Work Discipline}

Siswanto $(2013$, p.291) states that work discipline is an attitude of respect, respect, obedience and obedience to applicable regulations both written and unwritten and able to carry it out and not avoid receiving sanctions if it violates the duties and the authority given to him. According to Siswanto (2013, p.291) states that there are several indicators of work discipline which include: (a) absent and timely, (b) accuracy and calculation, (c) obeying regulations and responsibilities, (d) compliance and fluency, (e) a harmonious and respectful atmosphere.

\section{- Work Motivation}

Robbins (2008, p.43) explains motivation is a willingness to try as optimal as possible in achieving organizational goals that are influenced by the ability of businesses to satisfy some individual needs. And according to Robbins and Coutler (2010, p.226) states that work motivation indicators can be measured based on: (a) physiological needs, (b) security needs, (c) social needs, (d) appreciation needs, and (e) ) self-actualization needs.

\section{$>$ Research Conceptual Framework}

Conceptual framework is a model that explains the relationship of theory with important factors that are known in a particular problem. The conceptual framework will connect theoretically between research variables namely the independent variable with the dependent variable (Erlina, 2011). Based on the theoretical basis and research problem formulation, the conceptual framework in this study, can be seen in the following figure:

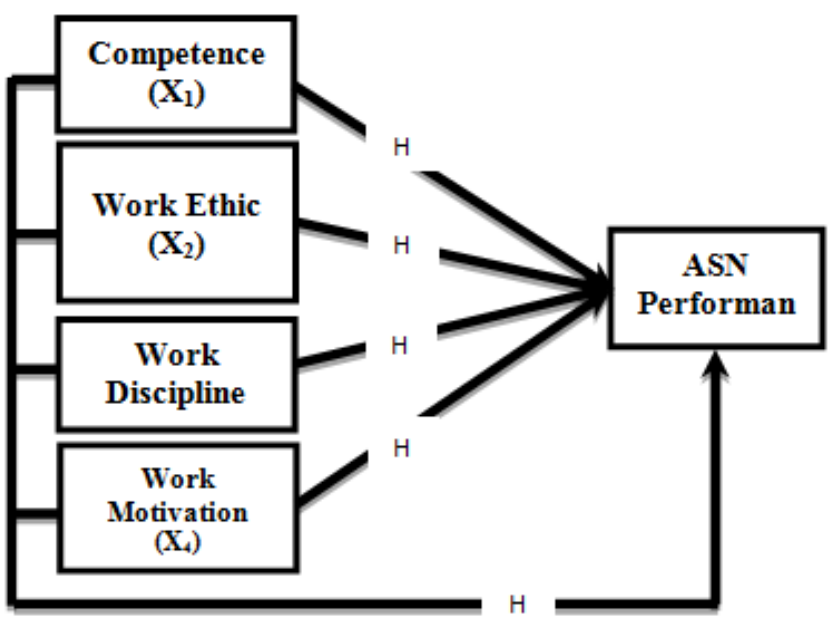

Fig 1:- Research Conceptual Framework

\section{$>$ Hypothesis}

Based on the conceptual framework above, it can be formulated a hypothesis in this study as follows:

H1 : Competence Has a Significant Effect on Performance of Government Employee at the Mentawai Islands District Health Office.

H2 : Work Ethic Has a Significant Effect on Performance of Government Employee at the Mentawai Islands District Health Office.

H3 : Work Discipline Has a Significant Effect on Performance of Government Employee at the Mentawai Islands District Health Office.

H4 : Work Motivation Has a Significant Effect on Performance of Government Employee at the Mentawai Islands District Health Office.

H5 : Competency, Work Ethics, Work Discipline and Work Motivation Simultaneously Have a Significant Effect on Performance of Government Employee at the Mentawai Islands District Health Office.

\section{RESEARCH METHOD}

\section{$>$ Type of Research}

Based on the formulation, objectives and research hypotheses, the method used in this study is quantitative research. Sugiyono (2017) states that the quantitative method can be interpreted as a research method based on the philosophy of positivism, used to research a population or a specific sample, data collection using research instruments, data analysis is quantitative / statistical, with the aim to test the hypotheses that have been set. From the description of expert opinion, this study analyzes the relationship between competence, work ethic, work discipline and work motivation on the performance of government employee.

\section{$>$ Population and Sample}

According to Sugiyono (2017) Population is a generalization area consisting of subjects or objects that have certain qualities and characteristics that are 
determined by researchers to be studied and then drawn conclusions, while the research sample is a limited number and part of the population, a portion of the population selected and representing the population (Muri, 2015, p.150). The sampling technique uses total sampling technique (overall sample), a sampling technique where the number of samples is equal to the population (Sugiyono, 2017). Because the total population is less than 100, the entire population is sampled (Sugiyono, 2017). Because the sample used is the same as the population, the sample in this study is the entire government employee of the Mentawai Islands District Health Office totaling 60 (sixty) people.

\section{RESULT}

\section{- Characteristics of Respondents}

General description of the characteristics of respondents in this study was measured based on 5 (five) categories, namely gender, age, education level, class, and years of service. The following characteristics of research respondents are presented in the table below:

\begin{tabular}{|c|c|c|c|}
\hline Profile & Category & Total & Percentage (\%) \\
\hline \multirow{3}{*}{ Gender } & Male & 25 & 41.67 \\
\cline { 2 - 4 } & Female & 35 & 58.33 \\
\hline \multirow{4}{*}{ Age } & $30-40$ year & 35 & 58.33 \\
\cline { 2 - 4 } & $40-50$ year & 22 & 36.67 \\
\cline { 2 - 4 } & $>50$ year & 3 & 5 \\
\hline \multirow{4}{*}{ Education } & S2 & 5 & 8.33 \\
\cline { 2 - 4 } & S1 & 26 & 43.33 \\
\cline { 2 - 4 } & D3 & 24 & 40 \\
\cline { 2 - 4 } & SLTA/SMK & 5 & 8.33 \\
\hline \multirow{4}{*}{ Class } & IV & 2 & 3.33 \\
\cline { 2 - 4 } & III & 49 & 81.67 \\
\cline { 2 - 4 } & II & 9 & 15 \\
\hline \multirow{4}{*}{ Sears of } & $<5$ year & 3 & 5 \\
\cline { 2 - 4 } & $5-10$ year & 11 & 18.33 \\
\cline { 2 - 4 } & $10-15$ year & 29 & 48.33 \\
\cline { 2 - 4 } & $15-20$ year & 10 & 16.67 \\
\cline { 2 - 4 } & $>20$ year & 7 & 11.67 \\
\hline
\end{tabular}

Table 5:- Characteristics of Research Respondents $(\mathrm{n}=60)$ Source: Primary Data, Mentawai Islands District Health Office, processed by Author 2020.

In the table above it can be seen that based on gender, most respondents were female, which was $58.33 \%$ while the rest were those who were male as much as $41.67 \%$. This data shows that the Government Employee of tMentawai Islands District Health Office is dominated by women, which certainly will provide opportunities to have high work performance in working.

Based on age, the majority of respondents are aged between 30-40 years which is as much as $58.33 \%$, then followed by the age group of $40-50$ years as much as $36.67 \%$ and those aged over 50 years which is as much as $5 \%$, this data shows that in general government employee of the Mentawai Islands District Health Office is still in its productive age and can provide objective answers to the questionnaire so as to provide opportunities to improve its performance in carrying out its tasks. Based on the level of education, most respondents were educated as bachelor (S1) as many as $43.33 \%$, then followed by a diploma level of as much as $40 \%$, with S2 as much as $8.33 \%$ and high school / vocational as much as $8.33 \%$. This data shows that in the scope of the government employee, the Mentawai Islands District Health Office has quite high education, because with the level of education plays a role in shaping the mindset in carrying out work. Thus the level of undergraduate education existing in the scope of the government employee of the Mentawai Islands District Health Office can contribute to improving the performance of the government employee.

Based on this group, the majority of respondents are group III which is $81.67 \%$, then followed by group II which is $15 \%$, and those who have group IV are $3.33 \%$. This data shows that in general government employee of the Mentawai Islands District Health Office already has a fairly high class. This shows that most of government employee of the Mentawai Islands District Health Office has a group or rank that has fulfilled certain occupational criteria.

Based on the years of service, most respondents had a working period of between 10-15 years as many as $48.33 \%$. followed by a working period of 5-10 years as much as $18.33 \%$, and working periods between $15-20$ years as much as $16.67 \%$, working periods over 20 years as much as $11.67 \%$, and working periods under 5 years as much as $5 \%$. This data shows that in general government employee of the Mentawai Islands District Health Office has a fairly high service period. This data shows that the government employee of the Mentawai Islands District Health Office has high work experience in carrying out tasks which will certainly have an impact on improving the performance of government employee.

\section{$>$ Description of Research Results}

The results in this study describe the effect of competence, organizational culture, and work conflict on the performance of BAZNAS Dharmasraya Regency employees, which is done by distributing questionnaires to respondents. The results of the study are based on respondents totaling 42 (fortytwo) respondents. In general, the results of this study can be seen in the following table:

\begin{tabular}{|c|c|c|c|c|c|}
\hline & N & Min & Max & Sum & Mean \\
\cline { 2 - 6 } & Stat & Stat & Stat & Stat & Stat \\
\hline Competence & 60 & 38 & 49 & 2536 & 42.27 \\
\hline Work Ethic & 60 & 39 & 49 & 2586 & 43.10 \\
\hline Work Discipline & 60 & 36 & 48 & 2571 & 42.85 \\
\hline $\begin{array}{c}\text { Work } \\
\text { Motivation }\end{array}$ & 60 & 36 & 49 & 2511 & 41.85 \\
\hline $\begin{array}{c}\text { ASN } \\
\text { Performance }\end{array}$ & 60 & 36 & 49 & 2558 & 42.63 \\
\hline $\begin{array}{c}\text { Valid N } \\
\text { (listwise) }\end{array}$ & 60 & & & & \\
\hline \multicolumn{7}{|c|}{ Std. Dev } & Questions & TCR & Desc. \\
\hline \multicolumn{7}{|c|}{ Statistic } & Item & $(\%)$ & \multicolumn{2}{c|}{} \\
\hline
\end{tabular}




\begin{tabular}{|c|c|c|c|c|}
\hline Competence & 2.893 & 10 & 84.54 & Good \\
\hline Work Ethic & 2.384 & 10 & 86.20 & Good \\
\hline Work Discipline & 3.085 & 10 & 85.70 & Good \\
\hline $\begin{array}{c}\text { Work } \\
\text { Motivation }\end{array}$ & 2.576 & 10 & 83.70 & Good \\
\hline $\begin{array}{c}\text { ASN } \\
\text { Performance }\end{array}$ & 3.659 & 10 & 85.26 & Good \\
\hline $\begin{array}{c}\text { Valid N } \\
\text { (listwise) }\end{array}$ & & & & \\
\hline
\end{tabular}

Table 6:- Variable Descriptive Analysis

Source: Primary Data, IBM SPSS Data Processing Results Ver. 24.0, 2020.

From table 6 above it can be seen that the results of the descriptive analysis for each of the variables in this study were obtained:

- Competence; The average competency statement item is 42.27\% and the Respondent Achievement Rate (TCR) is $84.54 \%$. This can be interpreted that each competency variable of the respondents has a good categorized response, but it can still be maximized so that efforts are needed to further improve the factors that effect the competency itself.

- Work Ethics; Having an average statement item work ethic variable is $43.10 \%$ and the Respondent Achievement Rate (TCR) is $86.20 \%$. This can be interpreted that each work ethic variable of the respondents has a good categorized response, but can still be optimized so that efforts are needed to further improve the factors that effect the work ethic itself

- Work discipline; Having an average of work discipline statement variable items is $42.85 \%$ and Respondents Achievement Rate (TCR) is $85.70 \%$. This can be interpreted that each variable of work discipline of respondents has a good categorized response, but can still be optimized so that efforts are needed to further improve the factors that effect work discipline itself.

- Motivate work; Having an average statement item of work motivation variable is $41.85 \%$ and Respondents Achievement Rate (TCR) is $83.70 \%$. This can be interpreted that each work motivation variable of the respondent has a good categorized response, but can still be optimized so that efforts are needed to further improve the factors that effect work motivation itself.

- ASN Performance; Having an average statement item ASN performance variable is $42.63 \%$ and Respondents Achievement Rate (TCR) is $85.26 \%$. This can be interpreted that each performance variable of the respondents has a good categorized response, but it has not been maximized so it needs efforts to further improve the factors that effect the performance of the ASN itself.

\section{Validity Test}

The validity test used is the Pearson Product Moment correlation technique by means of correlating the scores of each variable with the total scores. A variable / statement is said to be valid if the statement's score correlates significantly with the total score, to determine the validity of the questionnaire is done by comparing $\mathrm{r}_{\text {table }}$ with $\mathrm{r}_{\text {count }}$.
The validity test results using a program from IBM SPSS for Windows Version 24.0, which can be seen in the table below:

\begin{tabular}{|c|c|c|c|}
\hline Item & $\mathbf{r}_{\text {count }}$ & $\mathbf{r}_{\text {table }}$ & Results \\
\hline Competence $\left(\mathrm{X}_{1}\right)$ & 0.4997 & 0.2542 & Valid \\
\hline Work Ethic $\left(\mathrm{X}_{2}\right)$ & 0.4534 & 0.2542 & Valid \\
\hline Work Discipline $\left(\mathrm{X}_{3}\right)$ & 0.5762 & 0.2542 & Valid \\
\hline Work Motivation $\left(\mathrm{X}_{4}\right)$ & 0.4610 & 0.2542 & Valid \\
\hline ASN Performance $(\mathrm{Y})$ & 0.6540 & 0.2542 & Valid \\
\hline
\end{tabular}

Table 7:- Validity Test Results

Source: Primary Data, Results of IBM SPSS 24.0, 2020.

From table 7 above, it is known that the $\mathrm{r}_{\text {count }}$ value for all items of variable statement is greater than $r_{\text {table }}$, meaning that all statement items are declared valid.

\section{Reliability Test}

Reliability test is used to determine the reliability of a variable. A variable is said to be reliable if it has a Cronbach Alpha greater or equal to 0.60 and if it is smaller than 0.60 then the variable is said to be unreliable. The reliability test results using the program from IBM SPSS for Windows Version 24.0 of the variables in this study can be seen in the following table:

\begin{tabular}{|c|c|c|c|c|}
\hline No. & Variable & $\begin{array}{c}\text { Number } \\
\text { of Valid } \\
\text { Items }\end{array}$ & $\begin{array}{c}\text { Cronbach's } \\
\text { Alpha }\end{array}$ & Information \\
\hline 1 & Competence & 10 & 0.704 & Reliable \\
\hline 2 & Work Ethic & 10 & 0.683 & Reliable \\
\hline 3 & $\begin{array}{c}\text { Work } \\
\text { Discipline }\end{array}$ & 10 & 0.727 & Reliable \\
\hline 4 & $\begin{array}{c}\text { Work } \\
\text { Motivation }\end{array}$ & 10 & 0.694 & Reliable \\
\hline 5 & $\begin{array}{c}\text { ASN } \\
\text { Performance }\end{array}$ & 10 & 0.760 & Reliable \\
\hline
\end{tabular}

Table 8:- Reliability Test Results

Source: Primary Data, Results of IBM SPSS 24.0, 2020.

From table 8 above, we know the Cronbach's Alpha value for all variables> 0.6. The meaning is that the measuring instrument used of all variables in this study is reliable or trustworthy.

\section{> Multiple Linear Regression Analysis Test}

Based on the results of calculations using a computer using the IBM SPSS for Windows Ver. 24.0, from the Summary $^{\mathrm{b}}$ Model table, the ANOVA $^{\mathrm{a}}$ table and the Coefficients ${ }^{\mathrm{a}}$ table can be made a recap table for the results of the regression coefficient, $\mathrm{t}_{\text {count }}$, significance value, $\mathrm{F}_{\text {coun }}$ value, and $\mathrm{R}$ Square value $\left(\mathrm{R}^{2}\right)$. The results can be seen in the following table: 


\begin{tabular}{|c|c|c|c|}
\hline Variable & Coef. Regression & t count & Sig. \\
\hline Constant & 19.974 & & \\
\hline $\mathrm{X}_{1}$ & 0.544 & 4.631 & 0.000 \\
\hline $\mathrm{X}_{2}$ & 0.760 & 5.980 & 0.000 \\
\hline $\mathrm{X}_{3}$ & 0.333 & 3.482 & 0.001 \\
\hline $\mathrm{X}_{4}$ & 0.504 & 5.115 & 0.000 \\
\hline $\mathrm{F}_{\text {hitung }}=68.755$ & Sig. 0.000 & & \\
\hline $\mathrm{R}^{2}=0.833$ & & & \\
\hline
\end{tabular}

Table 9:- Recap of Multiple Regression Analysis Test Results

Source: Primary Data, processed by the author, 2020.

From table 9 above, the regression equation model for the effect of competence, work ethic, work discipline and work motivation on ASN performance is as follows:

$$
\begin{aligned}
& Y=19.974+0.544 X_{1}+0.760 X_{2}+0.333 X_{3}+0.504 \\
& X_{4}+e
\end{aligned}
$$

From the regression equation above, it can be interpreted as follows:

- The constant value $(\alpha)$ is 19.974 meaning that without the effect of competence, work ethic, work discipline, and work motivation, the ASN performance already exists at $19.97 \%$.

- The value of the competency regression coefficient $\left(b_{1}\right)$ is 0.544 , meaning that for each increase in one unit of competence, ASN performance increases by $54.4 \%$.

- The value of the work ethic regression coefficient $\left(b_{2}\right)$ is 0.760 , meaning that for each increase in one work ethic unit, the ASN performance rises by $76 \%$.

- The value of the work discipline regression coefficient $\left(b_{3}\right)$ is 0.333 meaning that each increase in one work discipline unit then the ASN performance increases by $33.3 \%$.

- The value of the regression coefficient of work motivation $\left(b_{4}\right)$ is 0.504 meaning that each increase in one unit of work motivation increases ASN performance by $50.4 \%$.

\section{$>$ Partial Test ( $t$ Test)}

This t-test is intended to determine the effect of partial (individual) competence, work ethic, work discipline and work motivation on ASN performance. T test results using the IBM SPSS for Windows Ver. 24.0, from table 9, the $t_{\text {value }}$ obtained by the calculation results:

- Competency Variables; The $t_{\text {count }}$ for the competency variable is 4.631 with a probability of significance of 0.000 or less than 0.05 . With $\mathrm{df}=60-4=56$, a $\mathrm{t}_{\text {table }}$ of 2.00324 is obtained, then $t_{\text {count }}>t_{\text {table }}$ or $4.631>2.00324$, as a result $\mathrm{Ho}$ is rejected and $\mathrm{Ha}$ is accepted. The competency variable has a significant effect on performance of government employee, so it can be concluded that the hypothesis (H1) which reads competence has a significant effect on performance of government employee of the Mentawai Islands District Health Office is accepted, thus the first hypothesis (H1) is accepted.
- Work Ethic Variable; The $\mathrm{t}_{\text {count }}$ for the work ethic variable is 5.980 with a significance probability of 0.000 or less than 0.05 . With $\mathrm{df}=60-4=56 \mathrm{a} \mathrm{t}_{\text {table }}$ of 2.00324 is obtained, then $t_{\text {count }}>t_{\text {table }}$ or 5.980>2.00324, consequently $\mathrm{Ho}$ is rejected and $\mathrm{Ha}$ is accepted. The work ethic variable has a significant effect on performance of government employee, it can be concluded that the hypothesis $(\mathrm{H} 2)$ which reads the work ethic has a significant effect on performance of government employee of the Mentawai Islands District Health Office is accepted, thus the second hypothesis $(\mathrm{H} 2)$ is accepted.

- Work Discipline Variable; The $t_{\text {count }}$ for the work discipline variable is 3.482 with a significance probability of 0.001 or smaller than 0.05 . With $\mathrm{df}=60$ $4=56 \mathrm{at}_{\text {table }}$ of 2.00324 is obtained, then $\mathrm{t}_{\text {coun }} \mathrm{t}>\mathrm{t}_{\text {table }}$ or $3.482>2.00324$, consequently $\mathrm{Ho}$ is rejected and $\mathrm{Ha}$ is accepted. Work discipline variables has significant effect on performance of government employee, it can be concluded that the hypothesis (H3) which says work discipline has a significant effect on performance of government employee of the Mentawai Islands District Health Office is accepted, thus the third hypothesis (H3) is accepted.

- Work Motivation Variable; The $t_{\text {count }}$ for the variable work motivation is 5.115 with a significance probability of 0.000 or less than 0.05 . With $\mathrm{df}=60-4=56$ a table of 2.00324 is obtained, then $t_{\text {count }}>t_{\text {table }}$ or 5.115>2.00324, as a result $\mathrm{Ho}$ is rejected and $\mathrm{Ha}$ is accepted. Work motivation variable has a significant effect on the performance of government employee, it can be concluded that the hypothesis (H4) which says work motivation has a significant effect on the performance of government employee of the Mentawai Islands District Health Office is accepted, thus the fourth hypothesis (H4) is accepted.

\section{Simultaneous Test (F Test)}

The F test (model feasibility) is intended to determine the effect of independent variables (competence, work discipline, work ethic, and work motivation) simultaneously (together) on dependent variables (ASN performance). The results of this test use IBM SPSS Ver 24.0 for Windows, from processing the data obtained ANOVA test results that can be seen in table 9, obtained $\mathrm{F}_{\text {count }}=68.755$ with a significance probability of 0.000 . The probability of significance is less than 0.05 . With $\mathrm{df}=\mathrm{n}-(\mathrm{k}$ - 1) $=60-(5-1)=56$ obtained $F_{\text {table }}$ of 2.54 , then $F_{\text {count }}>$ $F_{\text {table }}$ or $68.755>2.54$ with a significance level of 0.000 or $\alpha$ 0.05 as a result Ho is rejected and Ha accepted. Variable competence, work ethic, work discipline and work motivation simultaneously have a significant effect on performance of government employee of the Mentawai Islands District Health Office. It can be concluded that the fifth hypothesis (H5) which reads "Competency, Work Ethic, Work Discipline and Work Motivation simultaneously have significant effect to performance of government employee of the Mentawai Islands District Health Office was accepted, then the fifth hypothesis (H5) can be accepted. 


\section{$>$ Determination Coefficient Test $\left(R^{2}\right)$}

Analysis of the coefficient of determination for competence, work ethic, work discipline and work motivation on the performance of government employee of the Mentawai Islands District Health Office was carried out using the IBM SPSS for windows 24.0 program. From the results of data processing presented in table 9 , the results of the calculation of the regression estimation, obtained value of the adjusted determination coefficient or $\mathrm{R}$ Square = 0.833 means that $83.3 \%$ variation of all independent variables (competence, work ethic, work discipline and work motivation) can explain dependent variable (ASN performance), while the remaining $16.7 \%$ is explained by other variables not examined in this study.

Because the value of $\mathrm{R} 2$ is close to 1 (one), the contribution (effect) of independent variables (competence, work ethic, work discipline and work motivation) simultaneously to the dependent (ASN performance) is large.

\section{- Effect of Competence on ASN Performance}

The first objective of this study was to determine the effect of competence on ASN performance. The results of statistical analysis using multiple linear regression showed that the first hypothesis was accepted, so it can be concluded that the first hypothesis (H1) which reads competence has a significant effect on the performance of government employee of the Mentawai Islands District Health Office was accepted, thus the first hypothesis (H1) was accepted.

The results of this study are in line with the results of research by Mohklas (2015), Happy Y. Mogot, et al. (2019), and Yenny (2018) that competence has a significant effect on performance. So, it can be concluded from the results of this study prove that the competency variable partially has a significant effect on performance of government employee of the Mentawai Islands District Health Office. This means that the competence of an agency is very important to note because competence has an effect on the performance results of an ASN which will also affect the performance of the agency. Therefore, agencies must pay more attention to the competencies of the ASN.

\section{$>$ Effect of Work Ethic on ASN Performance}

The second objective of this study was to determine the effect of work ethic on ASN performance. The results of statistical analysis using multiple linear regression showed that the second hypothesis (H2) was accepted, so it can be concluded that the second hypothesis (H2) which reads the work ethic has a significant effect on performance of government employee of the Mentawai Islands District Health Office was accepted, then the second hypothesis ( $\mathrm{H} 2$ ) is accepted. The results of this study are in line with the results of research Happy Y. Mogot, et al. (2019), Muhammad Bakri (2015), and Ikhsan Abd. Wahid (2016) that work ethic has a significant effect on performance. So it can be concluded from the results of this study proving that the research produced that the work ethic variable partially has a significant effect on the performance of government employee of the Mentawai Islands District Health Office, this means that if if the ASN work ethic in an agency is good and well controlled then the agency will able to control and be able to improve ASN performance.

\section{Effect of Work Discipline on ASN Performance}

The third objective of this study is to determine the effect of work discipline on ASN performance. The results of statistical analysis using multiple linear regression indicate that the third hypothesis $(\mathrm{H} 3)$ is accepted, so it can be concluded that the third hypothesis (H3) which reads work discipline has a significant effect on performance of government employee of the Mentawai Islands District Health Office, so the third hypothesis (H3) received. The results of this study are in line with the results of research Happy Y. Mogot., Et al (2019), Yenny (2015), and Ikhsan Abd. Wahid (2016) that work discipline has a significant effect on performance. So it can be concluded from the results of this study proving that the research produced that the work discipline variable partially has a significant effect on performance of government employee of the Mentawai Islands District Health Office, this means that work discipline has a significant effect in increasing ASN performance.

\section{Effect of Work Motivation on ASN Performance}

The fourth objective of this study was to determine the effect of work motivation on ASN performance. The results of statistical analysis using multiple linear regression showed that the fourth hypothesis was accepted, so it can be concluded that the fourth hypothesis (H4) which reads work motivation has a significant effect on performance of government employee of the Mentawai Islands District Health Office, so the fourth hypothesis (H4) is accepted. The results of this study support the results of the research of Ikhsan Abd. Wahid (2016), Novelisa, et al (2016), and Parmin, SE, MM., (2017) that work motivation has a significant effect on performance. So it can be concluded from the results of this study prove that work motivation variables partially have a significant effect on performance of government employee of the Mentawai Islands District Health Office. This result means that work motivation has a significant effect in improving ASN performance.

The Effect of Competence, Work Ethics, Work Discipline and Work Motivation on ASN Performance

The fifth objective of this study was to determine the effect of competence, work ethic, work discipline and work motivation on ASN performance. Based on research, the performance of government employee of the Mentawai Islands District Health Office is good seen from the response of respondents (TCR) of $85.26 \%$ stating that the performance of ASN is good. This means that the government employee of the Mentawai Islands District Health Office has been very serious in doing their work and trying to finish it on time. Based on the results of statistical analysis by testing the hypothesis of the ANOVA test (Simultaneous Test / F Test) obtained the fifth hypothesis is accepted, it can be concluded that the fifth hypothesis (H5) which reads Competency, Work Ethics, Work Discipline and Work Motivation simultaneously has a significant 
effect on performance of government employee of the Mentawai Islands District Health Office is accepted, then with the fifth hypothesis (H5) it can be accepted. The effect of competence, work ethic, work discipline and work motivation variables on the performance variable, the research is in accordance with that expressed by Ikhsan Abd. Wahid (2016), Hartati, et al., (2016), and Novelisa P. Budiman, et al., (2019) who argued that competence, work ethic, work discipline and work motivation simultaneously effect performance. So it can be concluded that the hypothesis of this study that competency, work ethic, work discipline and work motivation simultaneously have a significant effect on the performance of government employee of the Mentawai Islands District Health Office.

\section{CONCLUSION}

\section{A. Conclusions}

Based on the results of research and data processing that have been done before, some conclusions can be drawn as follows:

> Competency partially has a significant effect on performance of government employee of the Mentawai Islands District Health Office. Thus it can be said that the competency variable effects the performance of government employee of the Mentawai Islands District Health Office.

$>$ Work Ethic partially has a significant effect on performance of government employee of the Mentawai Islands District Health Office. Thus it can be said that the work ethic variable has an effect on improving the performance of government employee of the Mentawai Islands District Health Office.

$>$ Work Discipline partially has a significant effect on performance of government employee of the Mentawai Islands District Health Office. Thus it can be said that the variable work discipline effects on improving the performance of government employee of the Mentawai Islands District Health Office.

$>$ Work motivation partially has a significant effect on performance of government employee of the Mentawai Islands District Health Office. Thus it can be said that the variable of work motivation effects on improving the performance of government employee of the Mentawai Islands District Health Office.

$>$ Competency, work ethic, work discipline and work motivation simultaneously have a significant effect on performance of government employee of the Mentawai Islands District Health Office.

\section{B. Suggestions}

Based on the research findings and conclusions, the authors propose the following suggestions:

$>$ Researchers advise the government employee of the Mentawai Islands District Health Office to always comply with the regulations set by the agency.

$>$ Researchers suggest to the government employee of the Mentawai Islands District Health Office to be able to help other ASN with their competencies so that the work runs smoothly.
Researchers advise the government employee of the Mentawai Islands District Health Office to always have a sense of responsibility for the work done.

$>$ Researchers advise the government employee of the Mentawai Islands District Health Office to always carry out work in accordance with orders or instructions from superiors.

$>$ Researchers advise the government employee of the Mentawai Islands District Health Office to help one another in need of colleagues.

$>$ Researchers suggest that the government employee of the Mentawai Islands District Health Office be able to achieve the agency's work targets well, namely to provide the best service to the community.

$>$ Researchers advise the government employee of the Mentawai Islands District Health Office to have high motivation to achieve work targets.

$>$ Researchers advise the government employee of the Mentawai Islands District Health Office to complete the work on time.

\section{REFERENCES}

[1]. Erlina., 2011, Metodologi Peneltian Bisnis: Untuk Akuntansi dan Manajemen, Edisi kedua, Cetakan Pertama, USU Press, Medan.

[2]. Happy Y. Mogot, Christoffel Kojo, dan Victor P. K. Lengkong., 2019, Pengaruh Gaya Kepemimpinan, Etos Kerja, Kompetensi Dan Disiplin Kerja Terhadap Kinerja Karyawan Pada PT. PLN Cabang Manado., Jurnal EMBA, Vol.7 No.1, Januari 2019, Hal. 881 890.

[3]. Hartati, Gunawan, dan Abdul Razak Munir, 2016, Pengaruh Motivasi Kerja, Disiplin Kerja, dan Kompetensi Terhadap Kinerja Pegawai pada Dinas Pengelolaan Sumber Daya Air, Pertambangan dan Energi Kabupaten Soppeng., Jurnal Mirai Management, Vol. 1 No. 2, Oktober 2016, p.1-10.

[4]. Hasibuan, Malayu S. P., 2013, Manajemen Sumber Daya Manusia, Jakarta: PT Bumi Aksara.

[5]. Ikhsan Abd. Wahid, 2016, Pengaruh Motivasi, Etos Kerja Dan Disiplin Kerja Terhadap Kinerja Pegawai Negeri Sipil (PNS) Pada Dinas Kehutanan Dan Perkebunan Daerah Kabupaten Morowali., eJurnal Katalogis, Volume 4 Nomor 8, Agustus 2016, hlm 156-163.

[6]. Mangkunegara, Anwar Prabu., 2012, Evaluasi Kinerja Sumber Daya Manusia, Bandung: Penerbit Refika Aditama.

[7]. Mohklas., 2015., Pengaruh Kompetensi Dan Motivasi Terhadap Kinerja Pegawai Dengan Komunikasi Sebagai Variabel Moderating (Studi Pada Kecamatan Gayamsari Kota Semarang). Vol. 10 No. 2 Desember 2015: p. 99 - 119.

[8]. Muhammad Bakri, 2015, Pengaruh Etos Kerja, Kompetensi Dan Lingkungan Kerja Terhadap Kinerja Karyawan Pada PT. Hadji Kalla Di Makassar., Artikel Penelitian Dosen STIE Wira Bhakti Makassar, p.117-128. 
[9]. Muri A. Yusuf., 2015, Metode Penelitian: Metode Penelitian Kuantitatif, Kualitatif, dan Penelitian Gabungan, Jakarta: Prenadamedia Group.

[10]. Novelisa P. Budiman, Ivonne S. Saerang, dan Greis M. Sendow, 2016, Pengaruh Kompetensi, Motivasi, Dan Disiplin Kerja Terhadap Kinerja Karyawan (Studi Pada PT. Hasjrat Abadi Tendean Manado)., Jurnal EMBA, Vol. 4 No. 4, September 2016, Hal. 321-332.

[11]. Parmin, SE, MM., 2017., Pengaruh Kompensasi, Kompetensi Dan Motivasi Kerja Terhadap Kinerja Guru Tidak Tetap (GTT) Dengan Kepuasan Kerja Sebagai Variabel Intervening, Jurnal Fokus Bisnis., Vol. 16., No. 01., Bulan Juli 2017.

[12]. Robbins, Stephen P., 2008, Perilaku Organisasi, Jilid I dan II, alih Bahasa: Hadyana Pujaatmaja, Jakarta: Prenhallindo.

[13]. Robbins, Stephen P., dan Mary, Coulter., 2010, Manajemen, diterjemahkan oleh Bob Sabran, Wibi Hardani, Erlangga: Jakarta.

[14]. Ruky, Achmad S. 2006, Sistem Manajemen Kinerja, Jakarta: Gramedia Pustaka Utama.

[15]. Simanjuntak, Payaman J., 2005, Manajemen dan Evaluasi Kinerja, Jakarta: Lembaga Penerbit Fakultas Ekonomi UI.

[16]. Sinamo, Jansen H., 2011, Etos Kerja Profesional Navigator Anda Menuju Sukses. PT. Spirit Mahardika. Jakarata.

[17]. Siswanto, B. Sastrohadiwiryo., 2013, Manajemen Tenaga Kerja Indonesia, Pendekatan Administratif dan Operasional. Jakarta, Bumi Aksara.

[18]. Sudarmanto., 2011, Kinerja dan Pengembangan Kompetensi SDM, Cetakan Pertama, Yogyakarta, Pustaka Pelajar.

[19]. Suggiyono, 2017, Metode Penelitian Kuantitatif, Kualitatif, dan $R \& D$, Bandung. Alfabeta.

[20]. Sutisna, Muhari., 2012, Perilaku Konsumen dan Komunikasi Pemasaran, Bandung: PT. Remaja Rusdakarya.

[21]. Sutrisno, Edy., 2011, Manajemen Sumber Daya Manusia, Edisi Pertama, Cetakan Pertama, Jakarta: Prenada Media.

[22]. Yenny., 2018., Pengaruh Kompetensi, Motivasi Dan Disiplin Kerja Terhadap Kinerja Guru Pada Yayasan Pendidikan Imanuel Palu, e-Jurnal Katalogis., Volume 6., Nomor 2., Februari 2018., hlm 98-105., ISSN 2302-2019. 